\title{
Změny využití krajiny v důsledku stavby vodních nádrží
}

MAREK HAVLÍČEK, JANA UHROVÁ

Klíčová slova: využití krajiny - struktura krajiny - vodní nádrž - jižní Morava - staré topografické mapy

\section{SOUHRN}

Přispěvek se zabývá dopady budování vodních nádrží na změny využití krajiny v zátopových oblastech a v zázemí tří jihomoravských nádrží - Nové Mlýny, Vranov a Brno. Pro sledování vývoje využití krajiny byly použity dostupné staré topografické mapy: druhé rakouské vojenské mapování 1: 28800 (1836-1841), třetí rakouské vojenské mapování 1: 25000 (1876), československé reambulované mapy 1: 25000 (1933-1945), mapy z mapování Protektorátu Čechy a Morava (Messtischblätter) 1 : 25000 (1943), vojenské topografické mapování Československa 1 : 25000 (1953-1955), vojenské topografické mapování Československa 1: 25000 (1990-1991) základní mapy ČR1:10 000 (2014). Sledováno bylo devět základních kategorií využití krajiny: orná půda, trvalý travní porost, zahrada a sad, vinice a chmelnice, les, vodní plocha, zastavěná plocha, rekreační plocha, ostatní plocha. Změny využití krajiny se odehrávaly nejen ve vlastních zátopových oblastech, ale i v jejich širším zázemí (do 1 km). U všech tři vodních nádrží a v jejich zázemí byl ve zkoumaném období významný pokles podílu ploch trvalých travních porostů, byly zaznamenány i výrazné úbytky orné půdy, v prípadě Nových Mlýnů taktéž lesních ploch. V těsném zázemí vodních nádrží Vranov a Brno se po zprovozněních vodních děl rozvíjely významně především rekreační plochy. Dlouhodobý vývoj využití krajiny a jejich změn v zázemí vodního díla a v samotném zátopovém území byl dále hodnocen i s ohledem na míru ohroženosti pozemků vodní erozí na zemědělsky využívané půdě, a to před a po vybudování vodního díla Nové Mlýny.

\section{ÚVOD}

Sledování dlouhodobého využití krajiny má význam pro pochopení aktuálních i historických vazeb a vztahů v krajině. Při budování vodních nádrží je možné sledovat dva základní fenomény $v$ krajině, zánik krajinné struktury $v$ zatopeném území a vývoj využití krajiny v zázemí vodních děl po jejich vybudování. Jedním ze základních předpokladů pro hodnocení dlouhodobého využití krajiny a vývoje vodních ploch je studium starých topografických map [1]. Mapy středního měřítka umožňují získat základní přehled o způsobu využití krajiny větších územních celků [1-4], administrativně nebo i prírodně vymezených [5-6]. Zkoumání vývoje vodních ploch, zejména rybničních soustav s využitím starých map, má v České republice dlouhodobou tradici. První studie o vývoji vodních ploch na jižní Moravě využívaly Müllerovy mapy Moravy z r. 1716 [7]. Dějiny výstavby rybníků a vodních ploch na našem území byly postupně zpracovávány zejména historiky - např. Teplý [8], Hurt [9]. S využitím moderních geoinformačních technologií se stalo hodnocení historického vývoje vodních ploch taktéž predmětem zájmu geografů či geoinformatiků [10-13]. Kromě atraktivního tématu vývoje rybničních soustav se začínají postupně objevovat práce zaměěené na studium vývoje využití krajiny v okolí vodních nádrží [1, 14]. Vývoj využití krajiny v zátopovém území vodních přehrad Nové Mlýny a Brno byl zkoumán v několika studiích a pracích [1, 15-18]. Cílem príspěvku je vyhodnocení dopadů budování vodních nádrží na využití krajiny v těsném zázemí vodní nádrže a zhodnocení ztráty krajinné struktury zatopené vodním dílem. Detailnější struktura krajiny použitá pro míru ohroženosti pozemků vodní erozí byla zkoumána ze tří modelových území jen v zázemí vodního díla Nové Mlýny, protože pouze zde dlouhodobě převažovala zemědělská pưda, a Ize tak odvodit dopady socialistického způsobu hospodaření na krajinnou strukturu. Mezi základní výzkumné otázky řešené v tomto výzkumu patřila otázka společných trendů ve vývoji využití krajiny v zázemí vodních nádrží po jejich zatopení, popř. vliv ostatních faktorů na trendy ve vývoji využití krajiny a hledání odlišností $\checkmark$ modelových územích.

\section{MATERIÁL A METODY}

Dlouhodobé změny využití krajiny byly analyzovány za použití mapových vrstev vytvořených vektorizací nad mapovými sadami starých map $v$ prostředí ArcGIS. Pro systematické sledování změn využití krajiny ve třech modelových územích vodních nádrží Brno, Nové Mlýny a Vranov bylo využito celkem šest mapových sad vojenských topografických map a současné základní mapy. Použity byly následující mapové podklady:

- Druhé rakouské vojenské mapování 1 : 28800 (1836-1841),

— Tretí rakouské vojenské mapování 1:25000 (1876),

— Československé reambulované mapy 1:25 000 (1933-1945),

— Vojenské topografické mapování Československa 1:25000 (1953-1955),

— Vojenské topografické mapování Československa 1:25 000 (1990-1991),

- Základní mapa ČR 1: 10000 (2014).

Při př́pravě map využití krajiny byla použita metodika Výzkumného ústavu Silva Taroucy pro krajinu a okrasné zahradnictví, v. v. i. [1]. Tato metodika rozlišuje devět základních kategorií využití krajiny: orná půda, trvalý travní porost, zahrada a sad, vinice a chmelnice, les, vodní plocha, zastavěná plocha, rekreační plocha, ostatní plocha. Minimální mapovací plocha má velikost 0,8 ha. Kromě map využití krajiny byly vytvořeny v prostředí GIS (software ArcGIS) mapy počtu změn využití krajiny a mapy stabilně využívaných ploch (nezměněných ploch).

Vývoj využití krajiny v zázemí vodního díla a v samotném zátopovém území byl dále hodnocen i s ohledem na míru ohroženosti pozemků vodní erozí na zemědělsky využívané půdě, a to před a po vybudování vodního díla Nové Mlýny. Vodní dílo Nové Mlýny bylo pro tyto účely vybráno proto, že $v$ jeho zázemí dlouhodobě zůstávají zachovány zemědělské plochy, jejichž krajinná struktura má základní vliv na ohroženost pozemků vodní erozí. Zároveň zde 
byla dostupná podrobná mapa s detailním zákresem vrstevnic v plochém reliéfu před zatopením vodního díla. Použita byla mapa 1:10 000 z 50. let 20. století a letecké snímky z roku 1940 zobrazující detailní strukturu krajiny před kolektivizací zemědělství. Pro tento účel došlo k rozšírení zázemí vodního díla. Hranice zájmové oblasti vychází z morfologie terénu a ohraničují hydrologicky uzavřené celky. Podobně jako v jiných zemích, tak i v České republice se dnes ke stanovení ohroženosti vodní erozí používá tzv. univerzální rovnice pro výpočet dlouhodobé ztráty půdy vodní erozí USLE [19]. Rovnice stanovuje průměrnou roční ztrátu půdy na základě šesti faktorů zohledňujících vliv morfologie terénu (sklon a délku svahu), využití území, klimatické poměry, půdní poměry a i prípadné vlivy již realizovaných protierozních opatření. V podmínkách České republiky je doporučeno použít pro většinu půd jednotnou hodnotu prípustné ztráty půdy, tedy maximální velikosti eroze půdy, ve výši 4 t.ha ${ }^{-1} \cdot$ rok $^{-1}$ [20]. Tato hodnota platí díky složení půdního profilu právě i pro oblast vodního díla Nové Mlýny. Při detailní struktuře krajiny byly sledovány následující kategorie využití krajiny: bažina, cesta, hráz, hřiště, lada, les, lom, louka, pole, rozptýlená zeleň, sídlo, sad, vinice, voda, zahrada, železnice, nejmenší mapovací jednotka byla stanovena na 0,05 ha.

\section{VYMEZENÍ ÚZEMÍ}

Změny využití krajiny podmíněné vybudováním vodních nádrží byly hodnoceny v širším kontextu, proto byla modelová území chápána jako nejbližší okolí vodních nádrží ve vzdálenosti 1 km od aktuální vodní hladiny. Tato vzdálenost byla zvolena s ohledem na vliv vodního díla na rozvoj nejbližšího okolí, zejména možnosti budování rekreačních ploch, zánik zemědělských areálů, popř. zastavěných ploch a navazující infrastruktury. Aktuální vodní hladina vodních nádržl byla převzata z prostorové databáze ZABAGED z ČÚZK ze současnosti (rok 2014).

$\checkmark$ přispěvku byly hodnoceny změny využití krajiny ve trech modelových územích: vodní nádrž Brno, vodní dílo Nové Mlýny, vodní nádrž Vranov. Nejstarší vodní nádrží z těchto tři modelových území je Vranov, tato přehrada byla budována v letech 1930-1933. Voda zaplavila údolí řeky Dyje pobliž hranic s Rakouskem. Vzniklá přehrada je dlouhá cca $30 \mathrm{~km}$ a zasahuje až pod hrad Bítov do údolí řeky Želetavky. Podle rozlohy (aktuální vrstva ZABAGED 643 ha) je to desátá největší přehrada v České republice. Rozloha studovaného území zahrnující vodní nádrž Vranov a zázemí vodního díla ve vzdálenosti do 1 km od aktuální vodní hladiny ze ZABAGED činí 5638 ha. Přehrada v dnešní době sloužl k energetickým a vodárenským účelům a k rekreaci [1].
Brněnská přehrada (vodní nádrž Brno, dřive Kníničská přehrada) je vodní nádrž vystavěná v letech 1936-1940 na řece Svratce. Přehrada vznikla zatopením území mezi Brnem a Veverskou Bítýškou a měří necelých $10 \mathrm{~km}$. Její účel byl dlouhou dobu zejména vodárenský a byla zásobárnou pitné vody pro Brno, $\checkmark$ dnešní době už je účel pouze energetický a rekreační [1]. Aktuální výměra vodní plochy v databázi ZABAGED je 207 ha. Sledované zázemí vodní nádrže Brno do 1 km od aktuální vodní hladiny díla včetně samotné vodní plochy má výměru 2298 ha.

Vodní dílo Nové Mlýny (Novomlýnské nádrže) je soustava tří přehradních nádrží, ležících na jihu Moravy na řece Dyji pod Pavlovskými vrchy. Horní nádrž je nazývána Mušovská, má rozlohu 528 ha a maximální hloubku 4 m, střední nádrž se jmenuje Věstonická, její rozloha je 1031 ha a je také poměrně mělká, největší hloubka je kolem 5 m, třetí z nádrží nazývaná dolní nebo Novomlýnská je ze všech tří největší a nejhlubší. Rozloha je 1668 ha a hloubka cca $8 \mathrm{~m}$. Do střední nádrže ústí řeky Jihlava a Svratka. Nádrže byly postaveny v 70. až 80. letech 20. století. Hlavním oficiálním účelem stavby bylo zamezení každoročním záplavám a zvýšení intenzity zemědělské výroby vybudováním systému zavlažovacích kanálů [1]. Výška hladiny vodního díla Nové Mlýny byla v minulosti několikrát upravována, především z důvodu ochrany přírody a krajiny (vedení nadregionálního biokoridoru ÚSES). Rozsah zátopových území se tedy poměrně liší od období vzniku vodního díla - výměry ze ZABAGED (horní nádrž: 654 ha, střední nádrž: 915 ha, dolní nádrž: 1468 ha). Kromě vodního díla Nové Mlýny byly sledovány i další prílehlé vodní plochy - Strachotínský rybník (41 ha), velká laguna (20 ha) a malá laguna (3 ha) v rekreační oblasti v zázemí vodního díla. Celková plocha modelového území vodních ploch a zázemí vodního díla Nové Mlýny činí 8538 ha.

\section{VÝSLEDKY A DISKUSE}

V první části hodnocení výsledků byly pro všechna tři modelová území vytvořeny přehledné tabulky s procentuálním podílem základních devíti kategorií využití krajiny pro šest časových období. Dalšími výstupy jsou ukázky map využití krajiny pro první (kolem roku 1840) a poslední sledované období (2014), které ilustrují zásadní rozdíly v dlouhodobém vývoji využití krajiny. Analýzami v GIS prostředí vznikly další mapové podklady charakterizující změny využití krajiny počet změn využití krajiny s hodnotami od 0 (nezměněné území) až po 5 (pětkrát změněné území) a stabilně využívané plochy.

\begin{tabular}{|c|c|c|c|c|c|c|}
\hline $\begin{array}{l}\text { Kategorie využití } \\
\text { krajiny }\end{array}$ & $1836-1838$ & 1876 & $1938-1945$ & 1953 & 1991-1992 & 2014 \\
\hline orná půda & 35,8 & 40,8 & 40,1 & 35,9 & 22,1 & 18,8 \\
\hline trvalý travní porost & 13,5 & 8,3 & 6,2 & 1,4 & 2,3 & 3,4 \\
\hline zahrada a sad & 0,0 & 0,1 & 0,3 & 0,8 & 0,1 & 0,0 \\
\hline les & 47,6 & 47,0 & 45,4 & 47,2 & 44,7 & 44,0 \\
\hline vodní plocha & 2,0 & 2,0 & 5,6 & 10,1 & 10,1 & 9,5 \\
\hline zastavěná plocha & 1,1 & 1,8 & 2,4 & 3,0 & 8,4 & 9,6 \\
\hline rekreační plocha & 0,0 & 0,0 & 0,0 & 1,6 & 12,3 & 14,7 \\
\hline Celkem & 100,0 & 100,0 & 100,0 & 100,0 & 100,0 & 100,0 \\
\hline
\end{tabular}




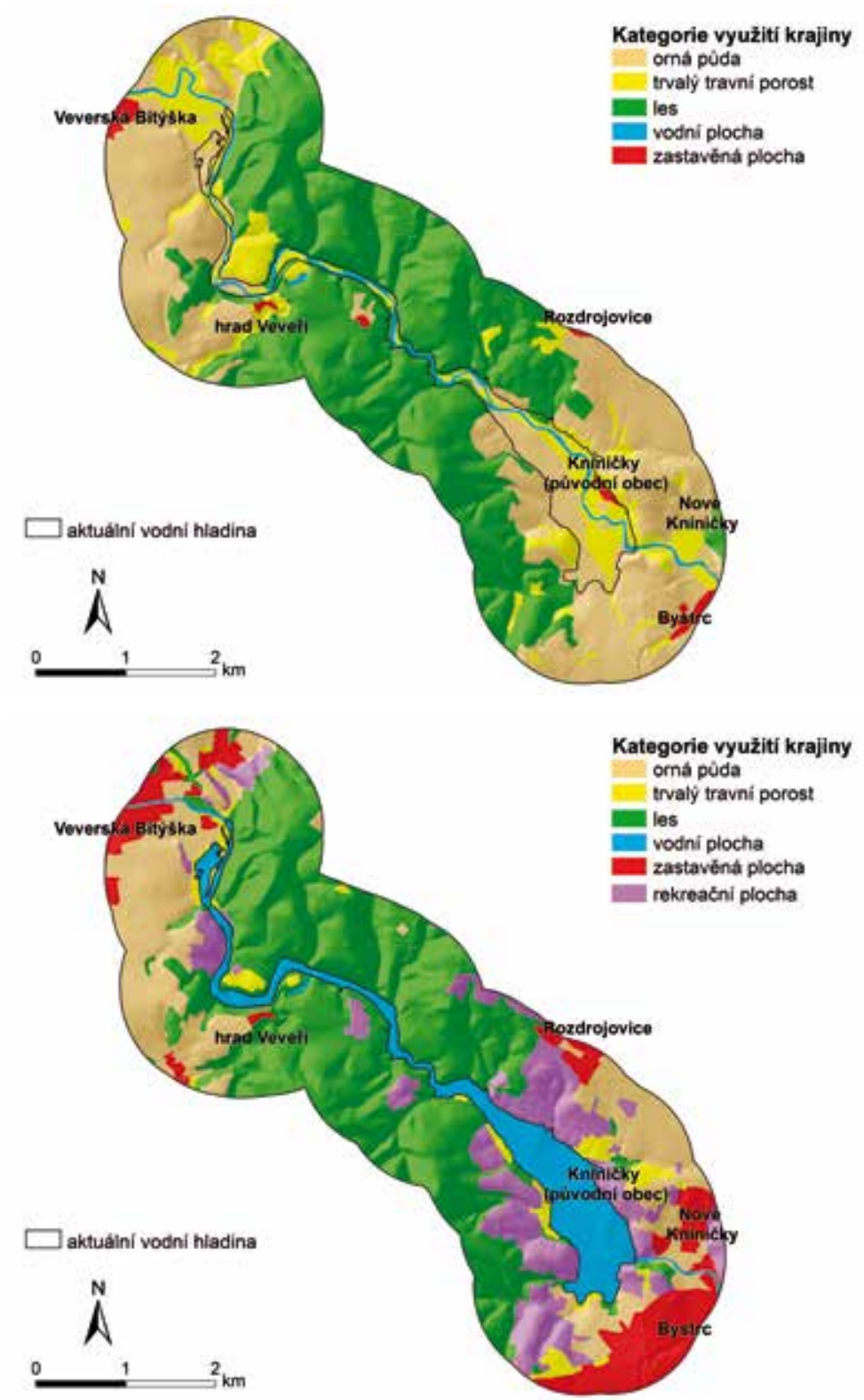

Obr. 1. Využití krajiny u Brněnské přehrady a jejího zázemí v roce 1836-1838 (nahoře) a 2014 (dole) Fig. 1. Land use in vicinity Brno Dam in 1836-1838 (above) and 2014 (down)

\section{Brněnská přehrada}

Střední část okolí Brněnské přehrady s vrchovinným reliéfem byla vždy zalesněná, podíl lesů byl ve všech šesti sledovaných obdobích oproti dalším kategoriím využití krajiny nejvyšší a mírně klesal až v posledních letech, predevším díky budování rekreačních areálů (tabulka 1). Nejvýraznější změny ve vývoji využití krajiny byly evidovány u orné půdy a trvalých travních porostů (tabulka 1, obr. 1), v obecné shodě s dlouhodobým vývojem využití krajiny v ostatních územích jižní Moravy a zázemí měst [5, 6]. Jejich klesající podíl byl způsoben budováním vodního díla (zaplavením území), ale i budováním rekreačních ploch a rozšiřováním zastavěných ploch (tabulka 1). Nárůst podílu vodních ploch byl zaznamenán v letech 1933 a 1945, jedna část území již na mapovém listu z roku 1945 má zaznamenánu hladinu vodní nádrže, zatímco na mapě z roku 1933 je ještě zakreslena původní obec Kníničky těsně před jejím zatopením. Pokles významu vodohospodářské funkce nádrže (nevyužívání jako zdroje pitné vody), vedl k posílení

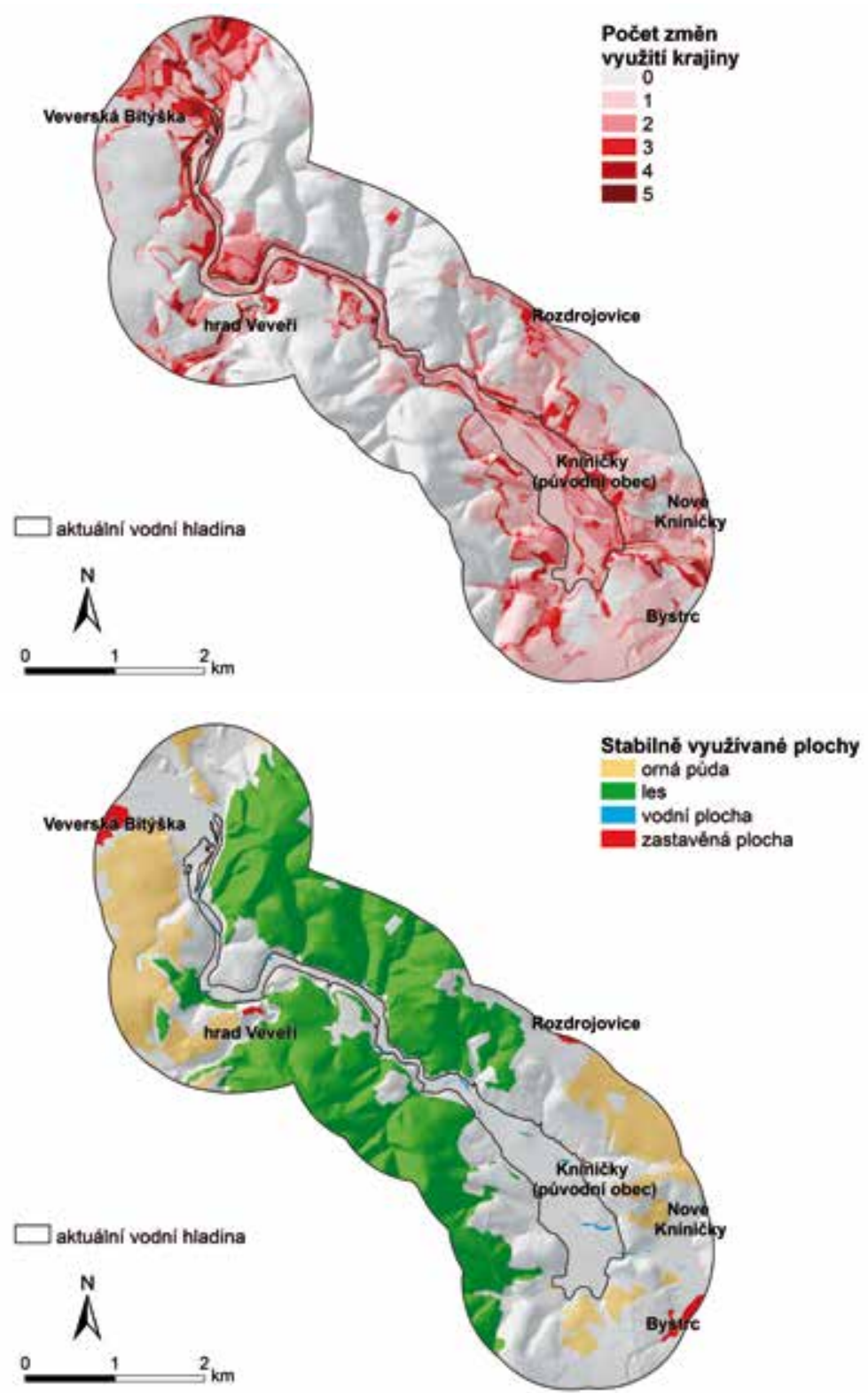

Obr. 2. Počet změn využití krajiny (nahoře) a stabilně využívané plochy u Brněnské přehrady (dole) a jejího zázemí

Fig. 2. Number of land use changes (above) a stable used areas (down) in vicinity of Brno Dam

rekreační funkce vodní nádrže a jejího zázemí. To se projevilo i v postupném růstu podílu rekreačních ploch (až na 14,7\%). Při hodnocení počtu změn byl sledován samostatně vývoj v zaplaveném území a v jeho zázemí. Ještě před budováním nádrže (zachyceném v celém rozsahu na mapách z roku 1954-1955) bylo v zátopovém území změněno téměř 50 \% území (obr. 2). Jednalo se především o úbytek trvalých travních porostů a jejich převod na ornou půdu, popř. střídavé změny mezi různými typy využití krajiny. Tyto trendy ve vývoji využití krajiny v období od roku 1836 do roku 1955 byly popsány i z jiných zájmových území jižní Moravy, např. z povodí Kyjovky [5, 6], Trkmanky [12], Svitavy [17]. Obdobné trendy ve vývoji využití krajiny byly však zaznamenány i v dalších částech České republiky [4], popř. v zahraničí [2, 3]. V zázemí vodní nádrže Brno byl následující podíl kategorií změn: 0-56,7 \%, 1-21,5 \%, 2-13,7 \%, 3-6,0 \%, 4-1,9\%, 5-0,3\%. Dynamika změn využití krajiny zde byla ze všech tří modelových území nejvyšší, byla koncentrována především do jižní části v těsném zázemí města Brna 


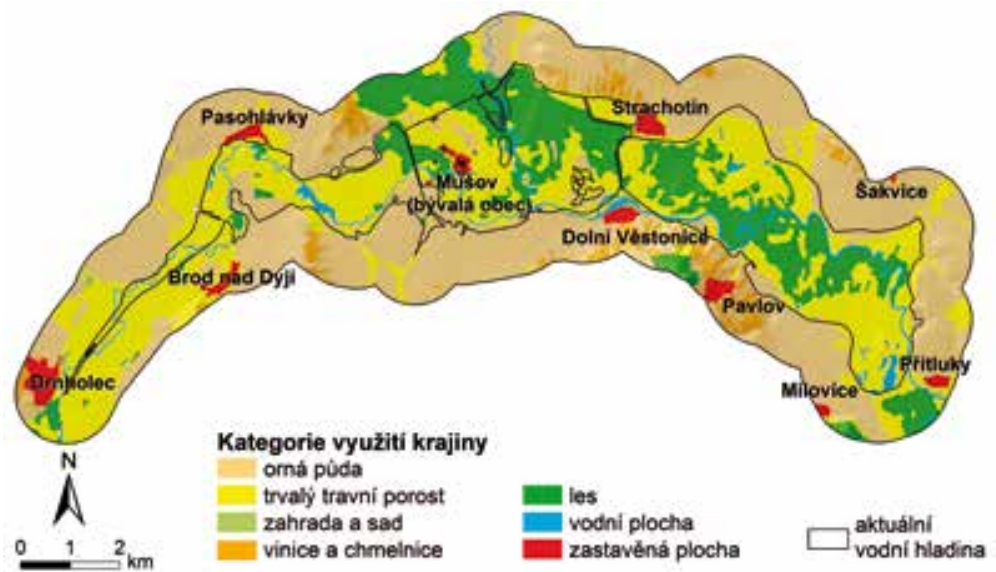

Obr. 3. Využití krajiny u vodního díla Nové Mlýny a jeho zázemí v roce 184

Fig. 3. Land use in vicinity of system of water reservoirs of Nové Mlýny in 1841

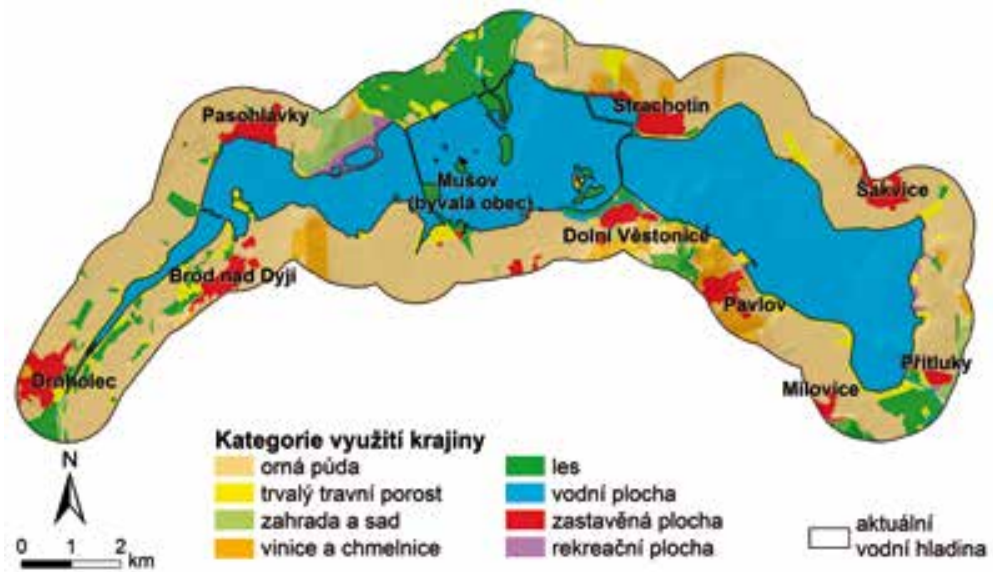

Obr. 4. Využití krajiny u vodního díla Nové Mlýny a jeho zázemí v roce 2014

Fig. 4. Land use in vicinity of system of water reservoirs of Nové Mlýny in 2014

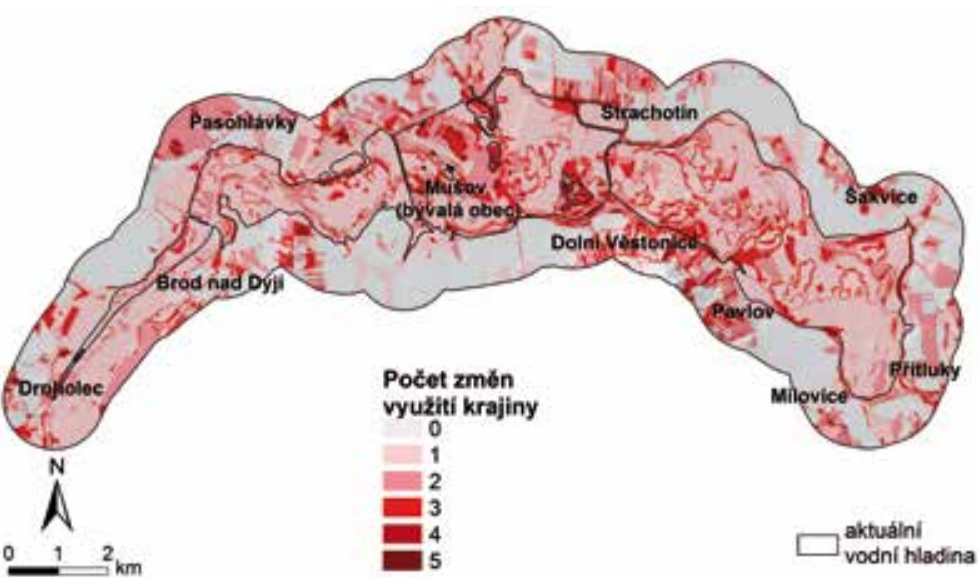

Obr. 5. Počet změn využití krajiny u vodního díla Nové Mlýny a jeho zázemí

Fig. 5. Number of land use changes in vicinity of system of water reservoirs of Nové Mlýny

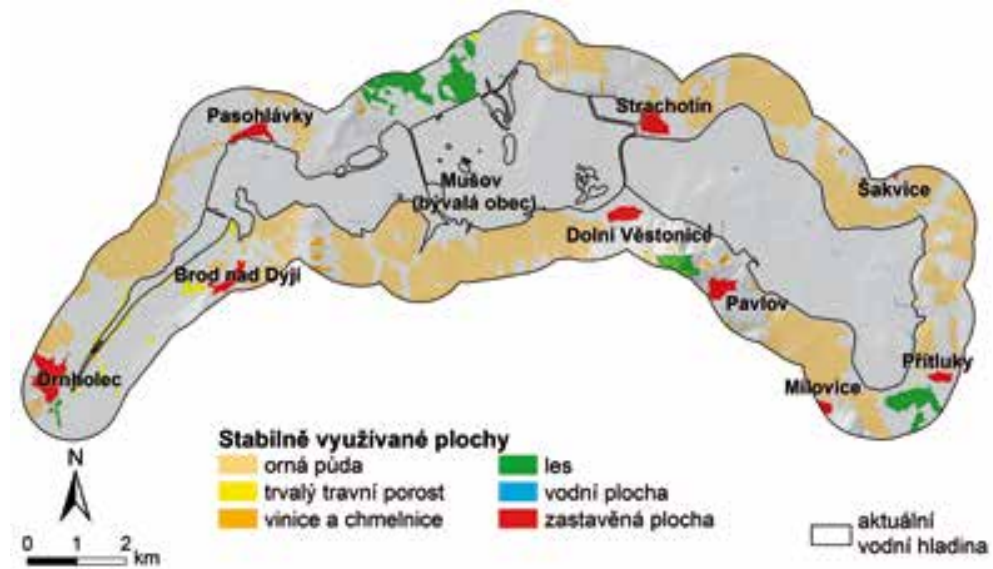

Obr. 6. Stabilně využívané plochy u vodního díla Nové Mlýny a jeho zázemí

Fig. 6. Stable used areas in vicinity of system of water reservoirs of Nové Mlýny

Tabulka 2. Vývoj využití krajiny v okolí vodního díla Nové Mlýny (podíl v \%)

Table 2. Development of land use in vicinity of system of water reservoirs of Nové Mlýny (share \%)

\begin{tabular}{|c|c|c|c|c|c|c|}
\hline Kategorie využití krajiny & 1841 & 1876 & 1933-1945 & 1954-1955 & 1991 & 2014 \\
\hline orná půda & 41,9 & 46,1 & 43,0 & 47,5 & 40,4 & 38,5 \\
\hline trvalý travní porost & 33,9 & 29,9 & 30,0 & 24,6 & 3,0 & 4,7 \\
\hline zahrada a sad & 0,3 & 0,2 & 0,2 & 0,7 & 4,2 & 1,8 \\
\hline vinice & 3,6 & 3,5 & 4,9 & 3,0 & 3,7 & 4,1 \\
\hline les & 15,5 & 15,4 & 16,2 & 17,3 & 5,6 & 8,4 \\
\hline vodní plocha & 2,6 & 2,5 & 2,2 & 3,1 & 38,3 & 37,0 \\
\hline zastavěná plocha & 2,2 & 2,4 & 3,4 & 3,7 & 4,3 & 4,9 \\
\hline rekreační plocha & 0,0 & 0,0 & 0,0 & 0,0 & 0,5 & 0,6 \\
\hline ostatní plocha & 0,0 & 0,0 & 0,1 & 0,1 & 0,0 & 0,0 \\
\hline Celkem & 100,0 & 100,0 & 100,0 & 100,0 & 100,0 & 100,0 \\
\hline
\end{tabular}


a severní části v okolí Veverské Bítýšky (obr. 2). Stabilně využívány byly během šesti sledovaných období následující kategorie využití krajiny: les (837 ha), orná půda (329 ha), zastavěná plocha (19 ha) a vodní plocha (7 ha). Stabilně využívány nebyly v zázemí vodní nádrže Brno žádné trvalé travní porosty (obr. 2). To bylo způsobeno jejich trvalým zánikem (zatopením území, převodem na ornou půdu, les, rekreační plochu), nebo dočasnou změnou využití krajiny (rozoráním a opětovným prevodem do trvalých travních porostů). Tlak na zánik trvalých travních porostů ke konci 19. století je spojován s potřebami záboru nových ploch orné půdy $v$ souvislosti s rozvojem pěstování technických plodin [12] a větší spotřebou potravin v zázemí průmyslových center [16].

\section{Vodní dílo Nové Mlýny}

V okolí vodního díla Nové Mlýny byl vždy vysoký podíl ploch orné půdy (tabulka 2, obr. 3 a 4). Budováním vodního díla tento podíl poklesl, protože došlo k zaplavení části ploch orné půdy (obr. 4). Nejvýraznější změny byly evidovány u kategorie trvalý travní porost (tabulka 2). Zatímco v roce 1841 tvorily trvalé travní porosty 33,9 \% území, v letech 1954-1955 už jen 24,6 \%. Tento pokles souvisel s intenzifikací zemědělství a obecně s nástupem agrární revoluce [1]. Budováním vodního díla Nové Mlýny zaniklo přibližně 1800 ha trvalých travních porostů. Obdobné výsledky byly zaznamenány i v jiných částech jižní Moravy, např. v povodí Kyjovky a Trkmanky [12], kde byl velmi významným fenoménem rozvoj cukrovarnictví s dopadem na rozšiřování ploch orné půdy. Dynamický pokles podílu byl zaznamenán i u lesních ploch (tabulka 2). Došlo zde k zatopení rozsáhlých ploch cenných lužních lesů (asi 1000 ha). Podíl vodních ploch se zvýšil skokově vybudováním vodního díla Nové Mlýny, které bylo dokončeno na konci 80. let 20. století. Budování vodního díla vedlo k zániku obce Mušov. Postupný růst ostatních zastavěných území odpovídal hodnotám z okolních studovaných území $[5,6,12,16]$. Rekreační plochy na rozdíl od vodní nádrže Brno nemají v tomto území tak vysoký podíl a význam, přesto v posledních letech zaznamenávají růst. Nejvýznamnější rekreační plochy jsou soustředěny především do oblasti Pasohlávek, kde již při budování vodního díla vznikl kemp, včetně samostatných vodních lagun po těžbě písku a štěrku. V posledních letech se i díky využití termálních pramenů v okolí kempu vybudovala wellness zařizení, obytné objekty a rozsáhlý areál akvaparku. Zázemí vodního díla Nové Mlýny má převážně zemědělský charakter, o čemž svědčí i poměrně významný podíl ploch vinic a sadů.

Analýza počtu změn v zaplaveném území ukázala, že před vznikem vodního díla bylo změněno priibližně $40 \%$ tohoto území. Změny zde probíhaly především $v$ souvislosti se zánikem trvalých travních porostů a střídavými změnami mezi jednotlivými kategoriemi využití krajiny. Jde o obdobné procesy jako $v$ okolních částech jižní Moravy [5, 6, 12]. Po vybudování vodního

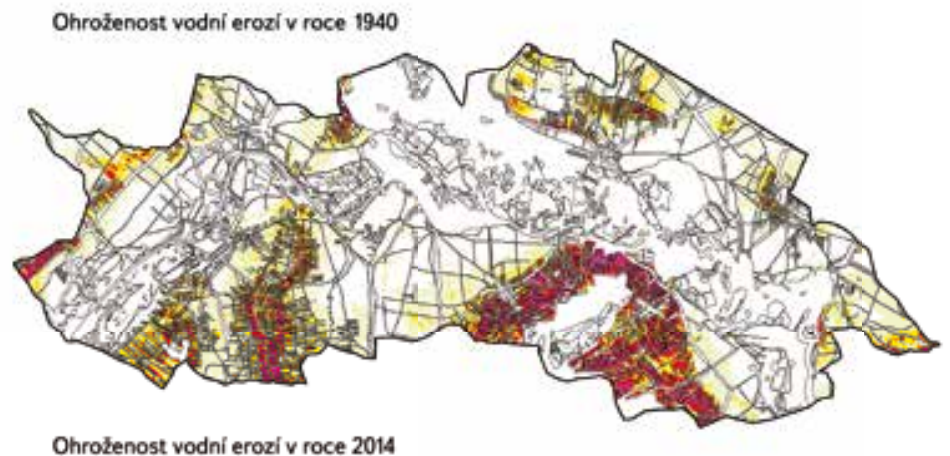

Ohrozenost vodni erozi v roce 2014

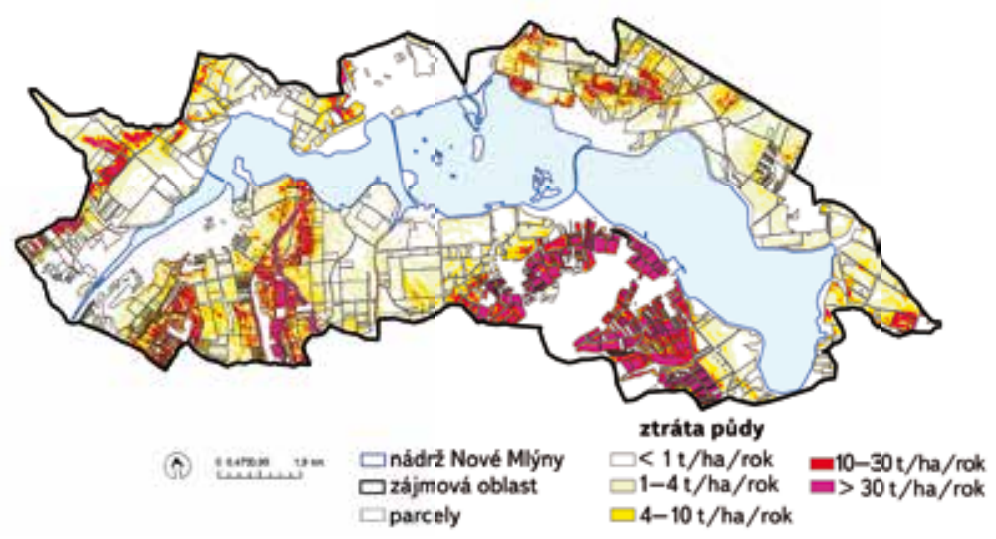

Obr. 7. Ohroženost vodní erozí v okolí vodního díla Nové Mlýny v roce 1940 (nahoře) a 2014 (dole)

Fig. 7. Vulnerability of water erosion in vicinity of system of water reservoirs of Nové Mlýny in 1940 (above) and 2014 (down)

díla Nové mlýny se na změnách krajiny nejvíce podílel vznik nových vodních ploch spojený se zánikem lužních lesů a nivních luk. Podíl kategorií celkového počtu změn využití krajiny v zázemí vodního díla Nové Mlýny byl následující: $0-43,9 \%, 1-24,3 \%, 2-20,6 \%, 3-7,7 \%, 4-3,1 \%, 5-0,4 \%$ (obr. 5). Dynamika změn využití krajiny v zázemí vodního díla Nové Mlýny souvisí především s celkovým úbytkem ploch trvalých travních porostů, střídáním zemědělských kultur (orná půda, vinice, zahrada a sad) a růstem podílu zastavěných ploch.

V zázemí vodního díla Nové Mlýny mezi stabilně využívanými plochami jednoznačně převládala orná půda (1 953 ha). Lesy byly na všech šesti mapovaných obdobích evidovány na 186 ha, jednalo se o fragmenty lužních lesů v okolí Křivého jezera u obce Nové Mlýny, v okolí soutoku Svratky a Jihlavy

Tabulka 3. Průmërné hodnoty ztráty půdy v t.ha-1.rok- v okolí vodního díla Nové Mlýny

Table 3. Average values of soil loss t.ha-1.year in vicinity of system of water reservoirs of Nové Mlýny

\section{Období Celá rešená oblast (včetně vodního díla) Oblast okolí vodního díla (bez plochy vodního díla)}

1940

Tabulka uvádí dosažené výsledky prưměrných hodnot ztráty půdy v jednotlivých obdobích (před a po vybudování vodní nádrže) pro celou rešenou oblast. Porovnání prưměrných hodnot ztráty pưdy v zázemí vodního dila v období před vybudováním a v období po vybudování potvrdilo předpoklad, že stav krajiny v období 40 . let 20 . století účinněji chránil půdu před vodní erozí. V prostoru současného vodního díla pak průměrná hodnota erozního smyvu dosahovala pouze 0,14 t.ha-1.rok?. Jednalo se o velmi ploché území s minimálním prevýšením - hloubka vodních nádrži vodního díla Nové Mlýny se pohybuje od $4 \mathrm{~m}$ do $8 \mathrm{~m}$. 

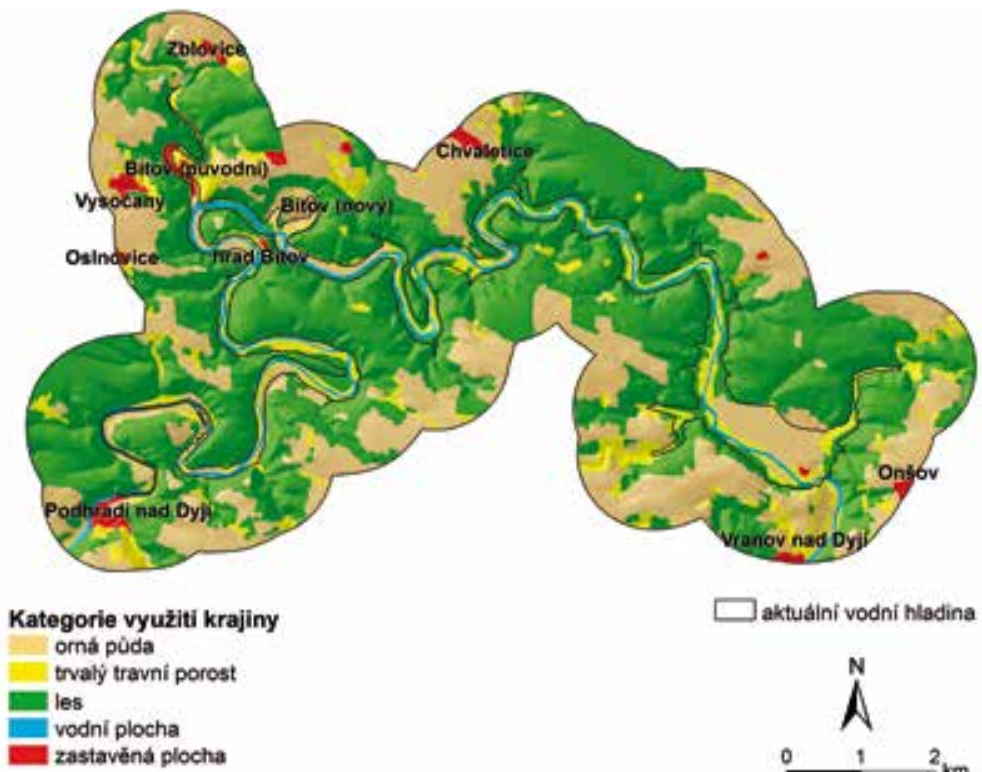

$\square$ aktualni vodni hladina
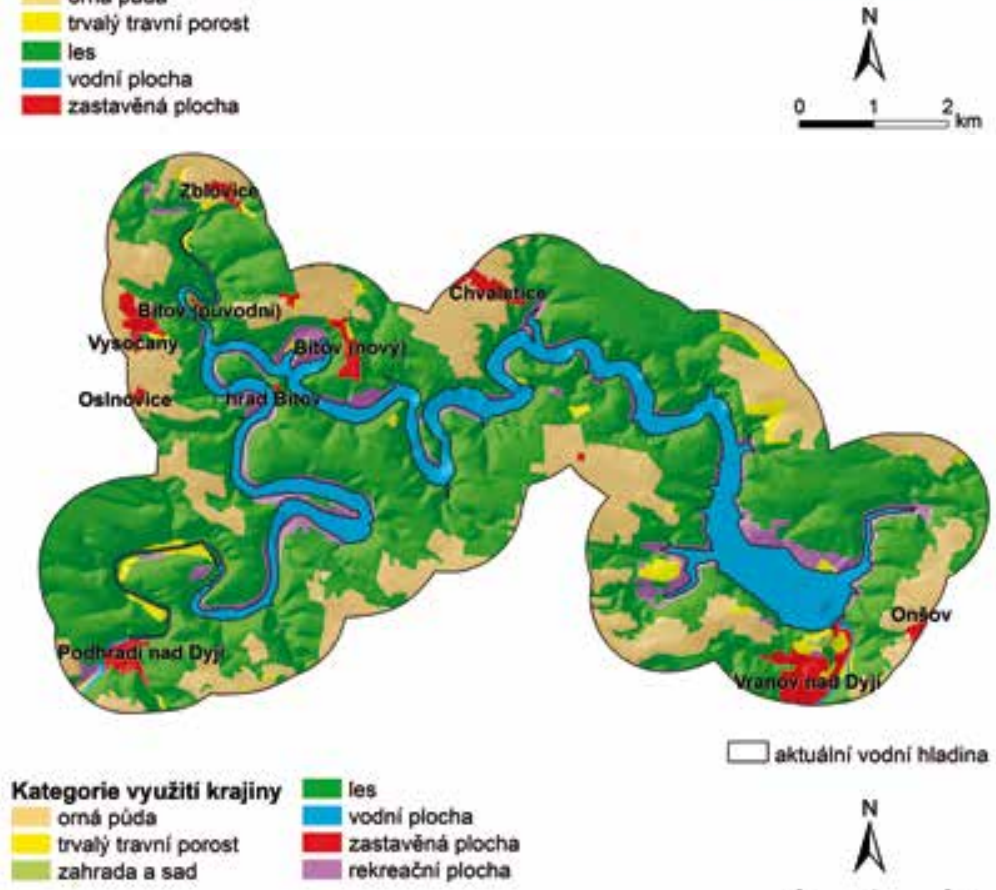

$\square$ aktualini vodni hladina

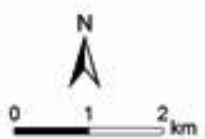

Obr. 8. Využití krajiny u Vranovské přehrady a jejího zázemí v roce 1838 (nahoře) a 2014 (dole) Fig. 8. Land use in vicinity of Vranov Dam in 1838 (above) and 2014 (down)

nedaleko Pasohlávek a lesy na svahu Pavlovských vrchů mezi Pavlovem a Dolními Věstonicemi (obr. 6). Stabilně využívané zastavěné plochy jsou reprezentovány starými jádry obcí a jejich výměra činila 151 ha. Stabilně využívané trvalé travní porosty zabíraly pouze 63 ha, byly zachovány jen jejich ojedinělé fragmenty v nivě a na terasách řeky Dyje v okolí Brodu nad Dyjí a Drnholce, popř. v okolí zbytků lužních lesů u Křivého jezera a u soutoku Svratky a Jihlavy (obr. 6). Mezi stabilně využívané plochy $v$ tomto regionu patřily i vinice (29 ha) s výskytem v těsném zázemí obcí Pavlov, Dolní Věstonice a Rakvice v oblasti tradičních vinařských tratí [1]. Stabilně využívané vodní plochy (12 ha) odpovídají původnímu korytu Dyje, které bylo identické v mapováních před zatopením území.
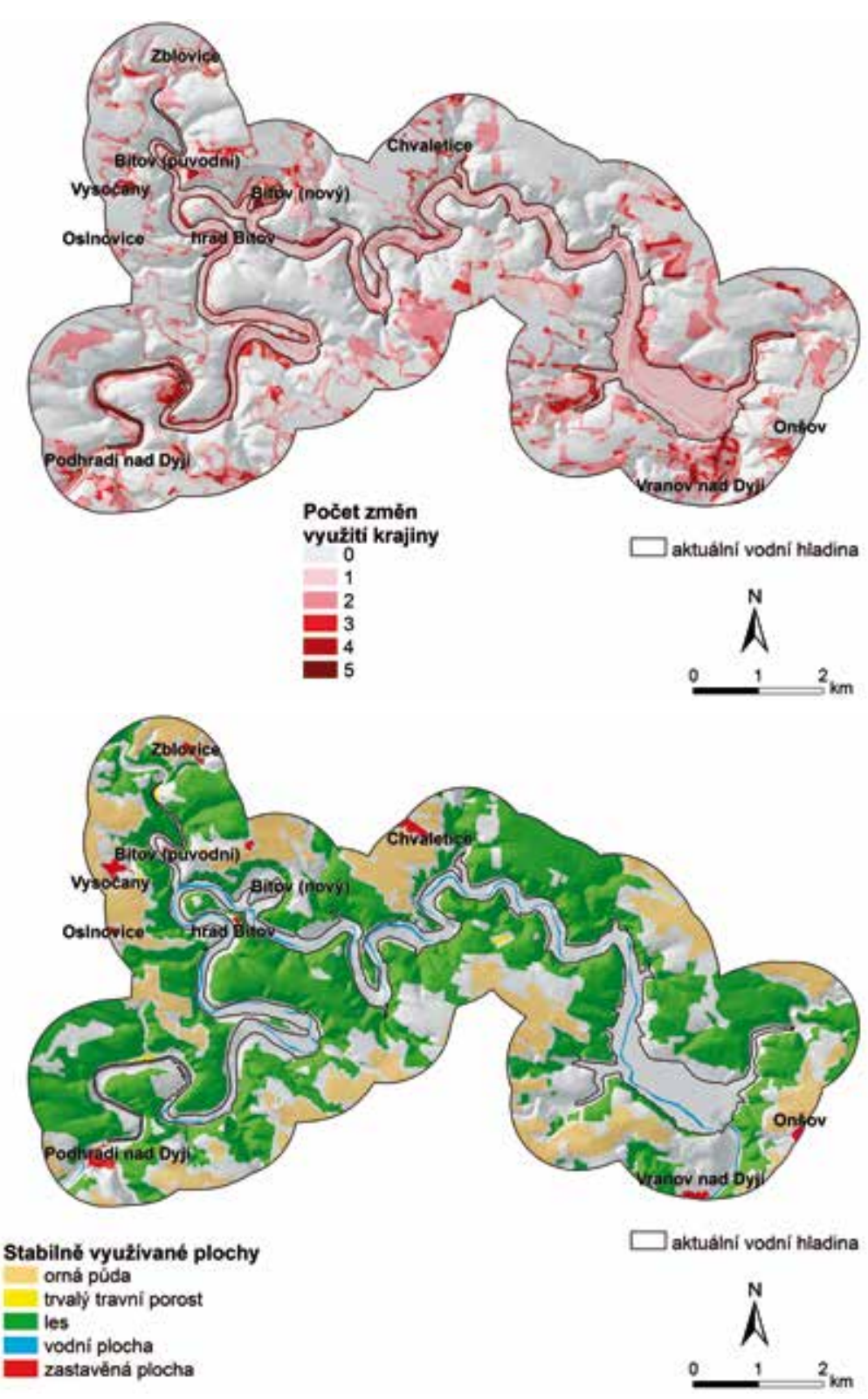

Obr. 9. Počet změn využití krajiny (nahoře) a stabilně využívané plochy u Vranovské přehrady (dole) a jejího zázemí

Fig. 9. Number of land use changes (above) a stable used areas (down) in vicinity of Vranov Dam

Na rozdíl od údolních nádrží byly vybudováním Novomlýnských nádrží zničeny prakticky všechny cenné biotopy zájmového území. K plošně nejrozsáhlejším prrírodním biotopům (obr. 3) patřily před zatopením území trvalé travní porosty reprezentované druhově bohatými aluviálními loukami [1]. Lesy predstavovaly jeden z největších komplexů lužního lesa ve střední Evropě, byly zastoupeny tvrdými luhy nížinných řek ve vyšších částech nivy a měkkými luhy nížinných řek doprovázejícími říční břehy a sníženiny. Četná mrtvá ramena hostila mokřadní vegetaci, především makrofytní vegetaci přirozeně eutrofních stojatých a tekoucích vod [1]. 
Tabulka 4. Vývoj využití krajiny v okolí Vranovské prehrady (podil v \%)

Table 4. Development of land use changes in vicinity of Vranov Dam (share\%)

\begin{tabular}{|c|c|c|c|c|c|c|}
\hline Kategorie využití krajiny & $1838-1841$ & 1876 & 1933 & 1954 & 1990 & 2014 \\
\hline orná půda & 26,8 & 30,5 & 25,3 & 20,4 & 19,7 & 19,1 \\
\hline trvalý travní porost & 9,3 & 8,7 & 3,4 & 5,7 & 2,5 & 2,1 \\
\hline zahrada a sad & 0,0 & 0,0 & 0,0 & 0,0 & 0,2 & 0,2 \\
\hline les & 60,1 & 56,8 & 58,6 & 60,0 & 59,9 & 60,1 \\
\hline vodní plocha & 2,6 & 2,8 & 10,6 & 11,2 & 11,4 & 11,5 \\
\hline zastavěná plocha & 1,2 & 1,2 & 2,1 & 2,1 & 2,5 & 2,6 \\
\hline rekreační plocha & 0,0 & 0,0 & 0,0 & 0,6 & 3,8 & 4,4 \\
\hline Celkem & 100,0 & 100,0 & 100,0 & 100,0 & 100,0 & 100,0 \\
\hline
\end{tabular}

Při hodnocení ztráty půdy erozním smyvem se vycházelo ze základní metody pro hodnocení intenzity vodní eroze na území ČR, tzv. univerzální rovnice ztráty půdy USLE:

$$
G=R \cdot K \cdot L . S . C . P\left[t . h a^{-1} \cdot r o k^{1}\right]
$$

kde $G$ je prưměrná roční ztráta půdy [t. ha-1.rok ${ }^{-1}$,

R faktor erozní účinnosti deště,

K faktor náchylnosti půdy k erozi,

L faktor délky svahu,

S faktor sklonu svahu,

C faktor ochranného vlivu vegetace,

P faktor vlivu protierozních opatření.

\section{Stanovení R faktoru}

Pro obě posuzovaná časová období (před a po vybudování nádrže) byla využita průměrná roční hodnota faktoru erozní účinnosti deště $\mathrm{R}=40 \mathrm{MJ} \cdot \mathrm{ha}^{-1} \cdot \mathrm{cm} \cdot \mathrm{h}^{-1}$ platná pro Českou republiku na základě dlouhodobé řady pozorování [20]. Tato hodnota vstupovala do výpočtu jako konstanta [21].

\section{Stanovení faktorů K, C a P}

Pro stanovení K faktoru bylo pro obě posuzovaná časová období využito údajů z celostátní databáze BPEJ. Na základě hlavní půdní jednotky byla přiřazena každému elementu vektorové vrstvy BPEJ hodnota K faktoru [20]

Stanovení hodnot C faktoru pro jednotlivá časová období vycházelo ze zkušeností hospodařících subjektů v jihomoravském regionu. Pro období pred vybudováním nádrže, tj. období 40. let 20. století, pro které byla sestavena mapa detailní struktury krajiny, se předpokládala následující prevevažující struktura pěstovaných plodin s uvedeným podílem ploch a C faktorem: obiloviny $(50 \%$, C faktor 0,132), víceleté pícniny (20\%, C faktor 0,01), brambory (10\%, C faktor 0,6), krmná řepa (10\%, C faktor 0,44). Taktéž pro aktuální období byla hodnota C faktoru stanovena podle podílu převažujících plodin, konkrétně obilovin, kukuřice a řepky olejné, přičemž průměrná hodnota C faktoru činila 0,325 [21].

Hodnoty $\mathrm{K}$ a C faktoru byly převedeny do rastrové podoby. P faktor vstupoval do výpočtů před návrhem opatření jako konstanta $\mathrm{P}=1$ [21].

\section{Stanovení faktoru LS}

Topografické faktory se počítají dohromady jako LS faktor. Pro plošně rozsáhlá území je metodicky doporučeno pro stanovení LS faktoru použit program USLE2D vyžadující data ve formátu Idrisi. Pro stanovení LS faktoru byl tedy použit program USLE2D, kde byl zvolen algoritmus, který využívá metodu výpočtu LS faktoru uvedenou v RUSLE (Revided Universal Soil Loss Equation). Výhodou této metody je plošné vyjádření LS faktoru. Pro stanovení faktoru LS je nutno zajistit či vygenerovat digitální model terénu (DMT). Pro období před výstavbou nádrže Nové Mlýny byl DMT s prostorovým rozlišením 10 m vytvořen jako kombinace výškových poměrů z dvou období. Jako první byly vektorizovány vrstevnice z vojenské mapy v měřítku 1: 10000 z 50. let minulého století. Aktuální terén byl vytvořen na základě výškového modelu z databáze ZABAGED. Dále je pro stanovení LS faktoru nutná vrstva „pozemkư“ rozčleňující území na dílčí odtokové plochy. Výpočet vychází z předpokladu, že hranice mezi dílčími plochami působí jako prekážky pro plošný povrchový odtok, čímž zde dochází k prèušení odtoku. Tím se snižuje délka odtokové dráhy a faktor L délky svahu. Pro období před výstavbou nádrže byla využita vrstva historického využití krajiny (viz postup výše). Pro období po výstavbě nádrže byla využita vrstva LPIS. Po provedení výpočtů byla konverzí dat vytvořena rastrová mapa LS faktoru vstupující do finálního výpočtu ztráty pưdy [21].

Výsledná mapa erozního ohrožení je tedy součinem jednotlivých faktorů $\checkmark$ podobě rastru či konstanty. Výpočty průměrné ztráty půdy vodní erozí probíhaly $\vee$ prostředí geografických informačních systémů (GIS). Výsledné erozní ohrožení zemědělské půdy v jednotlivých časových obdobích znázorňuje obr.7. Toto zobrazení má vypovídací hodnotu při určování nejvíce problematických míst v zázemí vodního díla Nové Mlýny z hlediska výše ztráty pưdy ze zemědělsky využívaných ploch v krajině. V prípadě obou časových období jsou nejvyšší hodnoty ztráty půdy (více než 30 t.ha-1.rok-1) zaznamenány v jižní části území na svazích v okolí nejvyšší kóty Pavlovských vrchů Děvín (554m n. m.) a v oblasti Dunajovických kopců. Větší hodnoty ztráty půdy jsou však evidovány v těchto částech území zejména $v$ současnosti, protože díky kolektivizaci zemědělství došlo ke scelování pozemků s negativními dopady na erozní poměry v území viz obr. 7. Drobná zemědělská držba se střídajícími plochami vinic, sadů, menších polí byla na většině území zrušena, za velmi negativní a necitelný zásah do struktury zemědělské krajiny Ize považovat i terasování svahů Dunajovických kopců. 


\section{Vranovská přehrada}

V zázemí vodní nádrže Vranov převládaly ve všech sledovaných obdobích lesy, jejich podíl dosahoval přibližně 60 \% (tabulka 4). Vodní nádrží Vranov bylo zatopeno pouze malé území lesních ploch (obr. 8). Druhý nejvyšší podíl měla v tomto území orná půda, její plochy se však postupně snižovaly na úkor vodního díla, lesư, zastavěných ploch a rekreačních ploch. Shodně jako u predešlých dvou vodních nádrží byl i u Vranova zaznamenán dlouhodobý pokles podílu trvalých travních porostů. Skokový nárůst podílu výměry vodních ploch spojený s budováním vodní nádrže byl zaznamenán už na mapě z roku 1933 (tabulka 4). Při budování vodní nádrže byla zatopena obec Bítov, jejím obyvatelům bylo umožněno se přestěhovat do nové vesnice Bítov v těsném zázemí vodní nádrže.

Před zatopením vodní nádrže Vranov bylo změněno přibližně 41 \% území $\checkmark$ zátopové oblasti. Změny souvisely zejména se zánikem trvalých travních porostů a jejich převodem do orné půdy, částečně se změnami lesních ploch. Zázemí vodní nádrže Vranov je nejvíce stabilním ze všech tří studovaných území, zde je uveden podíl kategorií změn: 0-67,9 \%, 1-12,9 \%, 2-13,7 \%, 3-4,0\%, 4-1,3\%, 5-0,2 \% (obr. 9). Stabilně využívané plochy v okolí vodní nádrže Vranov byly tvořeny především lesními plochami na svazích prilehlých k vodní nádržl (2 526 ha) a ornou půdou v méně príkrých územích dále od prèehrady (812 ha) viz obr. 9. Ostatní stabilně využívané plochy se vyskytovaly na výrazně menších plochách - vodní plochy původního toku Dyje na 78 ha, zastavěné plochy na 39 ha a trvalé travní porosty pouze na 11 ha (obr. 9). Stabilně využívané trvalé travní porosty se nacházely v lokalitách Česká louka, u obce Vysočany, u soutoku Dyje a Želetavky, Velká louka u Lančovského dvora a U rybničku v okolí Helenina Dvoru.

\section{ZÁVĚR}

Dopady budování vodních nádrží na využití krajiny ve třech modelových územích ukazuji jak na obecné trendy, tak i na specifické změny dané lokalizací vodní nádrže, vlivy bezprostředního okolí či převládající funkcí vodní nádrže. Dlouhodobý vývoj využití krajiny na území a v okolí všech tři vodních nádržl vykazuje shodné rysy ve výrazném úbytku podílu trvalých travních porostů, největší úbytek byl evidován u vodního díla Nové Mlýny a souvisel především se vznikem tohoto vodního díla. Přesto i před budováním vodních nádrží podíl trvalých travních porostů průběžně klesal. Jde o obecný trend v zemědělské krajině jižní Moravy, na kterém se podílel tlak na zábor nové orné půdy pro pěstování technických plodin a potravin, včetně zvýšené poptávky po cukrové řepě z konce 19. století. U vodního díla Nové Mlýny byly nenávratně zatopeny lužní lesy a podíl lesů je zde ze všech tří vodních nádrží nejnižší. Naopak v zázemí vodní nádrže Vranov se podíl lesů po budování vodního díla snížil pouze nepatrně. Podíl lesů u vodní nádrže Brno se snižoval i v období po vybudování vodní nádrže, zejména na úkor nově vzniklých rekreačních areálů. Plochy orné půdy se v zázemí vodních nádrží většinou zmenšily, nejvýraznější změny byly zaznamenány ve způsobu hospodaření na zemědělské půdě, spojené se zánikem drobné držby a negativními dopady na erozi půdy. Specifickým způsobem využití krajiny v okolí vodních nádrží jsou rekreační plochy, které postupně vznikly v zázemí všech tři vodních děl. Nejvyšší podíl rekreačních ploch je $v$ současnosti $v$ okolí vodní nádrže Brno, která leží v zázemí velkého sídla. Také v okolí vodní nádrže Vranov je významný podíl rekreačních ploch, přesto dopad na krajinu není tak markantní jako v okolí Brna s výrazně vyšším rekreačním potenciálem. V okolí vodního díla Nové Mlýny byly pưvodně vybudovány pouze kempy a jachtařský klub, v posledních letech ale v okolí obce Pasohlávky vyrostl významný akvapark, ubytovací kapacity a wellness zařízení, vázané na využití zdejších termálních pramenů. V oblasti vodního díla Nové Mlýny, vzniklého v široké Dyjsko-svratecké nivě, došlo po zatopení oblasti k likvidaci převážné většiny přírodovědně cenných biotopů a v současnosti tak ve vymezeném území nelze hledat vazby vegetace a fóry s využitím území v okolí. Naopak vodní nádrže Brno a Vranov, vázané na hluboká říční údolí, při jejichž zatopení zůstaly zachovány rozsáhlé plochy přírodních biotopů $\vee$ nejbližším okolí, Ize sledovat změny vegetace tak, jako v jakémkoliv segmentu krajiny, kde nedošlo k tak zásadním změnám využití krajiny. Nachází se zde i několik maloplošných zvláště chráněných území. Problematický je z hlediska ochrany prírody a krajiny antropogenní tlak na těchto plochách spojený s vysokou intenzitou pěší turistiky a cykloturistiky, zejména v okolí vodní nádrže Brno.

\section{Poděkování}

Přispěvek vznikl za podpory projektu NAKI DF13P01OVV012 - Zatopené kulturní a přirodní dědictvíjižní Moravy a vámci institucionálnípodpory Výzkumného ústavu Silva Taroucy pro krajinu a okrasné zahradnictví, v. v. i. (VUKOZ-IP-00027073).

\section{Literatura}

[1] HAVLÍČEK, M., HALAS, P., LACINA, J. a MLEJNKOVÁ, H. Změny využití krajiny u jihomoravských vodnich nádrží. Acta Pruhoniciana, 2014, 108, s. 25-34.

[2] HAASE, D. WALZ, U., NEUBERT, M., and ROSENBERG, M. Changes to Central European landscapes Analysing historical maps to approach current environmental issues, examples form Saxony, Central Germany. Land Use Policy, 2007, vol 24, No. 1, p. 248-263.

[3] SWETNAM, R.D. Rural land use in England and Wales between 1930 and 1998: Mapping trajectories of change with a high resolution spatio-temporal dataset. Landscape and Urban Planning, 2007, 81 (1-2), p. 91-103.

[4] SKALOŠ, J., WEBER, M., LIPSKÝ, Z., TRPÁKOVÁ, I., ŠANTRŮČKOVÁ, M., UHLIŘOVÁ, L., and KUKLA, P. Using old military survey maps and orthophotograph maps to analyse longterm land cover changesCase study (Czech Republic). Applied Geography, 2011, vol. 31, No. 2, p. 426-438.

[5] HAVLÍČEK, M., KREJČÍKOVÁ, B., CHUDINA, Z., and SVOBODA, J. Long-term land use development and changes in streams of the Kyjovka, Svratka and Velička river basins (Czech republic). Moravian Geographical Reports, 2012, vol. 20, No. 1, p. 28-42.

[6] HAVLIČCEK, M., PAVELKOVÁ CHMELOVÁ, R., FRAJER, J. a NETOPIL, P. Vývoj využití krajiny a vodních ploch v povodí Kyjovky od roku 1763 do současnosti. Acta Pruhoniciana, 2013, 104, s. 39-48.

[7] KOLAČEK, F. O vypuštěných rybnících jihomoravských. Sborník Českos/ovenské společnosti zeměpisné, 1930, s. 158-164.

[8] TEPLÝ, F. Příspěvky k dějinám českého rybníkářství. Praha, 1937, Min. zemědělství Republiky československé, $244 \mathrm{~s}$.

[9] HURT, R. Dějiny rybníkářství na Moravě a ve Slezsku, I. a Il. díl. Ostrava, 1960, Krajské nakladatelství $\checkmark$ Ostravě.

[10] PAVELKOVÁ CHMELOVÁ, R., FRAJER, J., PAVKA, P., DZURÁKOVÁ, M., and ADÁMEK, P. Identification and Analysis of Areas of Historical Ponds on the Basis of Available Map Bases: Case Study of the Chrudimka River Basin. AUPO. Geographica, 2012, vol. 43, No. 2, p. 117-132.

[11] FRAJER, J., KLADIVO, P., and GELETIČ, J. Reconstruction of extinct ponds using old maps, historical cadastres and the Digital Terrain Model of the Czech Republic of the $5^{\text {th }}$ Generation. Acta Universitatis Palackianae Olomucensis, Facultas Rerum Naturalium, Geographica, 2013, vol. 44, No. 1, p. 59-69.

[12] HAVLIČEK, M., PAVELKOVÁ, R., FRAJER, J., and SKOKANOVÁ, H. The long-term development of water bodies in the context of land use: The case of the Kyjovka and Trkmanka River Basins (Czech Republic). Moravian Geographical Reports, 2014, vol. 22, No. 4, p. 39-50.

[13] PAVELKOVÁ, R., FRAJER, J., HAVLIČEK, M., NETOPIL, P., ROZKOŠNÝ, M., DAVID, V., DZURÁKOVÁ, M., and ŠARAPATKA B. Historical ponds of the Czech Republic: an example of the interpretation of historic maps. Journal of Maps, 2016, 12 (Sup 1), p. 551-559.

[14] KEKEN, Z., PANAGIOTIDIS, D., and SKALOŠ, J. The influence of damming on landscape structure change in the vicinity of flooded areas: Case studies in Greece and the Czech Republic. Ecological Engineering, 2015, 74, p. 448-457.

[15] BORECKÁ, K. Brněnská přehrada - minulost, přítomnost a budoucnost. Bakalářská práce. Olomouc: Univerzita Palackého v Olomouci, Prírodovědecká fakulta, Katedra geografie, 2011, $55 \mathrm{~s}$.

[16] HAVLíČEK, M. Změny krajiny středního toku Svratky od poloviny 19. století do současnosti. In: Dreslerová, J., Packová, P. (eds.): Krajina v kontextu globálních změn - sborník ekologie krajiny č. 5. Sborník príspěvků z konference, Mendelova zemědělská a lesnická univerzita v Brně, 2008, CD-ROM

[17] LANG, M. Vývoj využití země povodí Svratky a Svitavy. Diplomová práce. Brno: Masarykova univerzita, Prírodovědecká fakulta, Geografický ústav, 2009, 70 s. 
[18] TOMANOVÁ, M. Rekonstrukce krajiny Novomlýnských nádrží. Diplomová práce. Olomouc: Univerzita Palackého v Olomouci, Přírodovědecká fakulta, Katedra geografie, 2013, 73 s.

[19] WISCHMEIER, W.H. and SMITH, D.D. Predicting rainfall erosion losses - a guide to conservation planning. Agriciultural. Hanbook, 1978, No. 537. Washington, DC: Department of Agriculture

[20] JANEČEK M. a kol. Ochrana zemědělské pưdy před erozí. Metodika. Praha: ČZU, 2012.

[21] HAVLIČEK, M., PAVLÍK, F., a KONVIT, I. Změny využití krajiny u jihomoravských vodních nádrží a jejich vliv na vodní erozi. In: Štiková, K., Pithart, D. (eds.) Říční krajina 10, Sborník príspěvků z konference, Brno, 2014, s. 92-94.

\section{Autoři}

Mgr. Marek Havlíček, Ph.D.

凶marek.havlicek@vukoz.cz

Ing. Jana Uhrová, Ph.D. ${ }^{2}$

凶jana.uhrova@vuv.cz

'Výzkumný ústav Silva Taroucy pro krajinu a okrasné zahradnictví, v. v. i. ${ }^{2}$ Výzkumný ústav vodohospodářský T. G. Masaryka, v. v. i.

Příspěvek prošel lektorským řízením.

\section{CHANGES IN LAND USE DUE TO THE CONSTRUCTION OF WATER RESERVOIRS}

\section{HAVLICEK, M.'; UHROVA J. ${ }^{2}$}

'The Silva Tarouca Research Institute for Landscape and Ornamental Gardening, p. r. i.

${ }^{2}$ TGM Water Research Institute, p. r. i.

Keywords: land use - landscape structure - water reservoir South Moravia Region - old topographic maps

This paper deals impacts of building of water reservoirs on land use changes in floodplains and adjacent areas of three reservoirs in southern Moravia Nové Mlýny, Vranov, Brno. To monitor the development of land use the old topographic maps were used: second Austrian military mapping 1:28 800 (1836-1841), third Austrian military mapping 1:25000 (1876) Czechoslovak revised maps $1: 25000$ (1933-1945), mapping the Protectorate of Bohemia and Moravia (Messtischblätter) 1:25000 (1943), Czechoslovak military topographic mapping 1:25 000 (1953-1955), military topographic mapping 1:25000 of Czechoslovakia (1990-1991), basic maps of the Czech Republic 1: 10000 (2014). Nine basic categories of land use were monitored: arable land, permanent grassland, garden and orchard, vineyards and hop gardens, forest, water area, built-up area, recreational area, other area. Land use changed not only in their own floodplains, but also in their wider hinterland (up to $1 \mathrm{~km}$ ). For three reservoirs and their adjoining areas a significant reduction of permanent grassland and arable land was observed. In the case of Nové Mlýny there was also detected a considerable decrease in forest areas. After construction of dams Vranov and Brno recreation areas were significantly expanded on their close hinterlands. The assessment of the long-term development of land use and land use changes in the background of the water reservoirs and in the floodplain area was further evaluated in the light of the vulnerability of the land to water erosion on agricultural land before and after the construction of system of water reservoirs of Nové Mlýny. 